\title{
PROKLITIK PRONOMINA PERSONA BAHASA TABA
}

\section{TABA LANGUAGES PERSONA LISTING PROKLITICS}

\author{
Mujahid Taha \\ Kantor Bahasa Maluku Utara \\ Jalan Raya Pertamina, Jambula, Pulau Ternate \\ Ponsel: 081242356519
}

\begin{abstract}
Abstrak
Penelitian ini bertujuan untuk mengetahui bentuk proklitik pronomina persona pertama, kedua, dan ketiga bahasa Taba (BT). Metode yang dipakai adalah metode kumpul data dan analisis data. Data penelitian ini merupakan morfem yang mengandung unsur proklitik yang melekat pada kata kerja (verba), kata depan (partikel preposisi), dan kata benda (nomina) yang bersifat singularis posesif. Sumber data penelitian ini adalah data lisan yang dituturkan langsung oleh penutur asli BT di Desa Waigitang, Kecamatan Pulau Makeang, Kabupaten Halmahera Selatan, Provinsi Maluku Utara. Berdasarkan hasil penelitian, ditemukan kata kerja BT berproklitik pronomina persona pertama dan jamak, persona pertama: $k$-, $n$-, (benda), dan $n$ - (insani), persona pertama jamak: tit/tat- dan $a-$; persona kedua tunggal dan jamak, persona kedua tunggal pada morfem $m$ dan persona kedua jamak pada morfem $h$-; dan persona ketiga tunggal pada morfem $i$-, serta persona ketiga jamak pada morfem $l$ -
\end{abstract}

Kata kunci: proklitik, pronomina persona, pronomina tunggal, pronomina jamak, bahasa Taba

\begin{abstract}
This study aims to find out the first, second, and third forms of personal prclitital pronouns of the Taba (BT) language. The method used is the method of data collection and data analysis. The data of this study are morphemes that contain proclitic elements attached to verbs (verbs), prepositions (preposition particles), and singular possessive nouns (nouns. The source of this research data is oral data that was told directly by BT native speakers in Waigitang Village, Pulau Makeang District, South Halmahera Regency, North Maluku Province. Based on the results of the study, it was found the BT verb with the first and plural personal pronouns, first person: $k$-, $n$-, (objects), and n- (human), first person plural: tit/ tat- and a-; the second person is singular and plural, the singular second person in the m-morpheme and the plural second persona in the morpheme $h$-; and the third third person in the $i$-morpheme, and the third person plural in the l-morpheme.
\end{abstract}

Keywords: proclitic, person pronoun, single pronoun, plural pronouns, Taba language

\section{Pendahulaun}

Peneliti bahasa Taba, Bowden (2001) merincikan wilayah pengguna bahasa Taba yaitu terutama di sisi timur Pulau Makeang, beberapa bagian Pulau Moti dan Kayoa, serta di sejumlah desa pada bagian pesisir selatan pantai Halmahera. Komunitas orang Taba yang cukup besar tinggal di daerah transmigrasi Malifut, dekat dengan Kecamatan Kao di semenanjung utara Pulau Halmahera. Selain itu, terdapat komunitas pendukung Taba yang jumlahnya cukup signifikan di pusat metropolitan, Ternate. Penutur bahasa ini juga dilaporkan ada di Pulau Bacan dan di daerah pedalaman Jailolo di Halmahera Barat.

Pulau Makeang merupakan rumah bagi dua bahasa yang berbeda, yaitu bahasa Taba (Makeang Timur) yang digunakan di sisi timur pulau Makeang dan bahasa Moi (Makeang Barat) yang digunakan di sisi baratnya. Pada umumnya, masyarakat Maluku Utara menyebut bahasa Taba dengan sebutan Makeang Dalam, sedangkan masyarakat penutur bahasa Taba menyebut bahasa Taba 
dengan sebutan Taba Llo. Makeang Luar oleh masyarakat penutur bahasa Taba disebut Taba Lik atau Moi Tesite.

Untuk melakukan identifikasi proklitik pronomina persona tunggal-jamak, kedua, dan ketiga dalam BT, penelitian ini dilakukan di Desa Waigitang sebagai desa konservatif BT, Kecamatan Pulau Makeang, Kabupaten Halmahera Selatan.

Penelitian ini belum pernah dilakukan sebelumnya. Akan tetapi, ada beberapa tinjauan dengan objek penelitian yang memiliki kemiripan dan dianggap masih relevan dengan penelitian ini. Misalnya, Hanafi (2009) membahas tentang Pola Kontruktursi Klitik Bahasa Tolaki. Dia mengelompokkan klitik menjadi dua bagian, yaitu proklitik dan enklitik. Proklitik ditemukan pada beberapa kata dalam kalimat bahasa Tolaki, antara lain au-pebahu lessu, 'kau mandi deluan' dari proklitik au- 'kau', kumbule ihawi 'kupulang kemarin' dari proklitik $k u$-'aku', to-peluarako mohina 'kita (berdua) keluar besok' dari proklitik to- 'kita (berdua)', tombe-peluarako mohina 'kita (lebih dari dua orang) keluar besok' dari proklitik tombe- 'kita (lebih dari dua orang) 'u-pondatapi ninggiro 'engkau mencuci sebentar' dari proklitik $u$ - 'engkau', $i$-tenai kadera ninggiro 'kalian angkat kursi sebentar dari proklitk $i$ - 'kalian', ki-perluarako mohina 'kami (berdua) keluar besok dari proklitik $k i$ 'kami (berdua)', kimbe-luarako mohina 'kami (lebih dari dua) keluar besok' dari proklitik kimbe-'kami (lebih dari dua)', no-poiso ronga inaku ninggiro owingi ' $\mathrm{ia} / \mathrm{dia}$ tidur dengan saya sebentar malam' dari proklitk no- 'ia/dia', dan ro-lumololoia mohina 'mereka lari besok' dari proklitik ro- 'mereka'. Dari data tersebut, dapat dilihat bahwa bentuk dasar proklitik yang melekat pada verba yaitu $\mathrm{ku}$-, to-, tombe-, $u_{-}, i-, k i-, k i m b e-$, no-, dan ro. Namun, pada proklitik no- dan $u$ - melekat pada adjektiva.

Penelitian klitik berikutnya adalah penelitian yang dilakukan Sultana (2017) yang membahas tentang Analisis Bentuk Klitik dalam Bahasa Sasak Dialek Meno-Mene. Dalam penelitian ini, ditemukan beberapa klitik, yaitu bentuk bahasa klitik Sasak termasuk fonem $/ \mathrm{k} /, \mathrm{m} /, / \mathrm{n} /$, /e/ dan morfem da, ta, na, KMO, dan ko, (2) proklitik: /K/, da, ta, na(3) inklitik: /M/, /n/, /e/, KMO, dan ko (4) proklitik dan inklitik: $/ \mathrm{K} /$, da, ta, danna, (5) Fungsi klitik bahasa Sasak adalah membentuk kata ganti dalam bentuk positif atau indra negatif, dan (6) arti klitik dari bahasa Sasak adalah membentuk kata tunggal dan kata ganti jamak.

Dari data hasil penelitian di atas, datadata yang diuraikan hanya berkaitan dengan proklitik. Dalam penelitian tersebut, proklitik dalam kalimat yang ditemukan antara lain $k$ lalo ojok bangket laun bian-bian 'aku akan pergi ke sawah nanti sore' dari proklitik $k$ 'aku', de-beitang inaq beras saq uah tegiling baruq to eler 'Anda ambilkan ibu beras yang sudah digiling di heller' dari proklitik de'Anda', ne-lalo ojok lendang laun bian 'dia akan pergi ke ladang nanti sore' dari proklitik ne- 'dia', berat irap ne-pede begawean mesaqmesaq 'berat rasanya mereka bekerja sendirisendiri' dari proklitik ne- 'mereka'. Dari hasil penelitian tersebut, disimpulkan bahwa proklitik bahasa Sasak terbagi atas dua bagian, yaitu berupa fonem dan morfem. Wujud proklitik fonem berupa satu fonem konsonan $k$ - 'aku', sedangkan wujud proklitik morfem berupa proklitik de- 'anda', dan ne'dia/mereka'.

Penelitian terbaru tentang klitik dilakukan oleh Aritorang (2018) yang membahas tentang Klitik Klausa Pasif Bahasa Manggarai Dialek Barat. Dalam penelitiannya, ditemukan (1) jenis klitik dalam bahasa Manggarai dialek Barat diklasifikasikan menjadi proklitik pronomina posesif, enklitik pronomina genetif, dan enklitik pronomina subjek; (2) bentuk proklitik pronomina posesif $d e$ - beralomorf dengan $d$ - dan tergolong sebagai proklitik pronomina posesif. Bentuk proklitik demengikuti bentuk berawalan konsonan $/ \mathrm{h} /$, sedangkan $d$ - mengikuti bentuk vokal; proklitik pronomina posesif untuk nama diri insan berupa $d i-$; nama diri bukan insan berupa de-, dan nama jabatan (status sosial) berupa de-; dan (3) enklitik pronomina genetif dan enklitik pronomina subjek dapat diwujudkan dalam kontruksi klausa pasif bahasa Manggarai dialek Barat. 
Beberapa data hasil penelitian yang menggambarkan tentang proklitik pronomina posesif yakni $d$ - dan/atau $d e$-(alomorf), $d$-aku 'milik saya' dari proklitik prominal posesif $d-$; de-hau'milikmu' dari proklitik prominal posesif $d e-$; $d$-tha 'miliknya' dari proklitik prominal posesif $d$-; $d$-ami'milik kami' dari proklitik prominal posesif $d$-; de-mi 'milik kalian' dari proklitik prominal posesif de-; dan $d$-ise 'milik mereka' dari proklitik prominal posesif $d$-. Selain itu, untuk nama diri (insan), yakni kata di-sius 'milik Sius', di-ema 'milik ayah', di-ende 'milik ibu', dan di-amang 'milik paman' semua berproklitik pronomina posesif $d i$. Selain itu, terdapat pula proklitik pronomina posesif untuk diri bukan insan, yakni de-mori 'milik Tuhan', de-dewa 'milik dewa', de-poti 'milik setan', de-acu 'milik anjing', dan de-manuk 'milik ayam', semua berproklitik pronomina posesif de-. Terdapat pula proklitik pronomina posesif pada nama jabatan (status sosial), yakni de-bupati 'milik bupati', de-camat 'milik capat', de-lurah 'milik lurah', de-pemeritah 'milik pemerintah' de-ro'eng 'milik rakyat', de-tu'a golo 'milik kepala suku', de-pendeta 'milik pendeta', depastor 'milik pastor', dan de-suster 'milik suster'. Proklitik pronomina posesif de- sama halnya pada nama diri, bukan insan. Selain data proklitik, ditemukan pula data enklitik pronomina genetif, namun pada kesempatan ini penulis hanya membandingkan tulisantulisan proklitik sebelumnya dengan penelitian yang dilakukan sekarang.

Berikut ini beberapa contoh kata yang berkelas kata verba, partikel preposisi, dan nomina yang terdapat proklitik pronomina persona pertama/tunggal - jamak, kedua, dan ketiga pada BT: persona pertama dan jamak pada kata $k$-am 'saya melihat' yang melekat pada verba am 'melihat' dari bentuk dasar yak, kata $t$-am 'kita melihat' yang melekat pada verba am 'melihat' dari bentuk dasar tit, kata a-am 'kami melihat' yang melekat pada verba am 'lihat/melihat' dari bentuk dasar am, dan kata $n$-am 'dia melihat' yang melekat pada verba $a m$ dari bentuk dasar $n$ dengan kata lain tidak ada pelesapan; persona kedua tunggal pada kata $m$-am 'kamu melihat' yang melekat pada verba am dari bentuk dasar meu, dan $h$ - am 'kalian melihat' yang melekat pada verba am dari bentuk dasar yang sama $h$, dengan kata lain tidak ada pelesapan; dan persona ketiga tunggal $i$-nini 'milik dia' yang melekat pada nomina nini dari proklitik dasar yang sama $i$ - dan tidak ada pelesapan. Sedangkan pada pronomina persona ketiga jamak, yaitu kata l-am 'mereka melihat' yang melekat pada kata kerja (verba) am dari bentuk dasar $l$, dengan kata lain tidak terdapat pelesapan. Selain $l$-, terdapat pula satu contoh pada kata si-nini 'milik mereka' yang melekat pada kata benda (nomina).

Dari beberapa hasil penelitian di atas, dapat disimpulkan bahwa struktur bahasabahasa daerah di Indonesia, dalam hal ini klitik terbagi atas proklitik dan enklitik. Penelitian tentang proklitik dan enklitik sudah banyak dilakukan. Akan tetapi, penelitian ini memfokuskan diri pada proklitik pronomina pesona BT. Dengan demikian, objek penelitian ini (bahasa dan wilayah) berbeda dengan penelitian yang lain.

Dengan demikian, penelitian ini sangat penting dilakukan. Hal ini disebabkan struktur mikro BT, khususnya pembahasan proklitik sejauh ini belum pernah diteliti atau ditulis secara ilmiah oleh siapa pun. Selain itu, penelitian ini dilakukan karena proklitik BT memliki keunikan bila dibandingkan dengan proklitik bahasa-bahasa lainnya. Kekhasan itu terlihat pada bentuk terikat. Dari hasil penelitian, proklitik sebagian besar melekat pada bentuk kata kerja (verba) dan kata benda (nomina). Hal serupa terdapat pula pada BT, namun ditemukan beberapa proklitik BT yang melekat pada kata depan (partikel preposisi) dan kata benda yang bersifat singularis posesif.

Dalam pemakaiannya, bentuk dasar verba, kata depan, (partikel preposisi), dan kata benda (singularis posesif) berfungsi sebagai bentuk dasar terikat. Artinya, verba, kata depan, dan kata benda tidak berdiri sendiri. Selain itu, penentuannya bergantung pada subjek. Oleh karena itu, tujuan dasar dari tulisan ini adalah upaya mengungkapkan fakta-fakta penggunaan proklitik pada BT secara ilmiah dan berfungsi sebagai penguatan serta pemanfaatan teori klitik. 
Teori yang digunakan dalam penelitian ini adalah teori klitika. Klitika diambil dari bahasa Yunani yaitu klinien, yang berarti bersandar atau melekat (Sarage, 2013). Yang dimaksud dengan klitika adalah morfem terikat yang bukan afiks. Dia bukan afiks karena dua sebab, yaitu: (1) merupakan bentuk singkat dari kata atau morfem bebas yang melekat pada kata lain. Klitika secara fonologis berasal dari suatu kata yang kehilangan stress (tekanan) yang melekat pada kata dekatnya, dan (2) bukan merupakan bentuk singkat, melainkan varian dari morfem bebas yang lain. Selain berbentuk singkat, klitika juga dapat berubah bentuk dan merupakan varian dari suatu kata atau frasa yang keadaannya melekat pada kata di dekatnya.

Menurut Lockwood (2002) dalam (Aritorang, 2018), klitik merupakan grammatical item yang secara sintaksis bertindak menyerupai sebuah kata penuh (full word). Tetapi, secara fonologis, klitik bertindak menyerupai afiks yang melekat pada sebuah kata yang mendahului atau mengikutinya. Mendefinisikan klitik sebagai bentuk-bentuk singkat, biasanya hanya terdiri atas satu suku kata, secara fonologis, tidak mendapat tekanan, kemunculannya dalam tuturan selalu melekat pada bentuk lain, tetapi dapat dipisahkan. Senada dengan itu, menurut Russi dalam (Aritorang, 2018), klitik mengacu pada unit-unit linguistik intermedia yang secara gramatikal berprilaku seperti kata atau frasa yang kepadanya mereka bergabung untuk membentuk frasa. Tetapi, secara fonologis, terikat pada kata yang berdekatan kepadanya, yang secara tradisional disebut host. Menurut Verhar, klitik merupakan bentuk terikat yang secara fonologis tidak mempunyai tekanan sendiri. Menurut Russi dalam (Aritorang, 2018), klitik merupakan salah satu morfem yang tidak terikat pada kelas kata tertentu.

Klitik (clitics) merupakan bentuk terikat yang secara fonologis tidak memiliki tekanan sendiri. Bentuk ini sebenarnya tidak dianggap sebagai morfem terikat karena dapat mengisi gatra pada tingkat frasa atau klausa. Klitik tidak mempunyai ciri-ciri kata karena tidak dapat berlaku sebagai bentuk bebas (Kridalaksana, 2001) dalam (Hanafi 2009:
294). Berdasarkan ciri bentuknya, Kridalaksana (2001) dan Pateda (1989) dalam (Hanafi 2009: 294-295) membagi klitik ke dalam dua bentuk, yaitu proklitik (proclitic) dan enklitik (enclitic). Proklitik adalah klitik yang secara fonologis terikat dengan kata yang mengikutinya, mis, $k u$-dalam $k u$ sebut. Adapun enklitik adalah klitik yang terikat dengan unsur yang mendahuluinya, misalnya, -nya dalam pulpennya $m u$ - dalam menjagamu, -lah dalam datanglah dalam bahasa Indonesia. Dengan demikian, enklitik adalah unsur tata bahasa yang tidak berdiri sendiri, tetapi selalu bergabung dengan kata yang mendahuluinya.

Selain klitik, perlu pula dijabarkan pronomina persona pertama, kedua, dan ketiga, masing-masing terbagi atas tunggal maupun jamak. Hal ini dilakukan karena objek dari kajian ini adalah klitik pada pronimna.

Jika ditinjau dari segi artinya, pronomina adalah kata yang dipakai untuk mengacu kepada nomina lain. Nomina perawat dapat diaju dengan pronomina dia atau ia. Jika dilihat dari segi fungsinya, dapat dikatakan bahwa pronomina menduduki posisi yang umumnya diduduki oleh nomina, subjek, objek, dan-dalam macam kalimat tertentu-juga predikat. Ciri lain yang dimiliki pronomina ialah bahwa acuanya dapat berpindah-pindah karena bergantung kepada siapa yang menjadi pembicara/penulis, siapa yang menjadi pendengar/pembicara atau siapa/apa yang dibicarakan, Alwi dkk (1998: 255-256).

Pronomina persona adalah pronomina yang dipakai untuk mengacu pada orang. Pronomina persona terbagi atas pertama, kedua, dan ketiga, dan sebagian terbagi pula atas tunggal dan jamak. Pronomina persona pertama tunggal yaitu saya, aku, $k u-$, dan $-k u$, sedangkan pada jamak yaitu kami; pronomina kedua tunggal yakni engkau, kamu, Anda, dikau, kau-, dan -mu, sedangkan pada jamak yakni kalian, kamu, sekalian, dan Anda sekalian; dan pronomina persona ketiga tunggal yakni ia, dia, beliau, dan -nya, sedangkan pada jamak yakni mereka (Alwi dkk, 1998).

\section{Metode}

Penelitian ini menggunakan pendekatan deskriptif, yaitu penelitian yang dilakukan 
semata-mata berdasarkan pada fakta-fakta yang ada atau fenomena yang secara empiris hidup pada penuturnya, sehingga yang dihasilkan atau yang dicatat berupa perian bahasa yang bisa dikatakan sifatnya seperti potret atau paparan seperti apa adanya (Sudaryanto, 1992: 62).

Jenis penelitian yang dilakukan adalah penelitian lapangan karena peneliti langsung mencari data kepada penutur asli BT. Samarin (1988: 26) menyatakan bahwa penelitian lapangan akan memudahkan informan maupun peneliti untuk mengumpulkan suatu korpus yang relevan secara kebudayaan dan tepat secara linguistik. Dengan demikian, penelitian ini diharapkan memiliki tingkat kesalahan yang lebih sedikit.

Data dalam penelitian ini adalah informasi yang berupa kata-kata lisan, ujaranujaran dalam bentuk cerita, ungkapan, maupun interaksi dari informan. Data tersebut dikumpulkan, diklasifikasi, dan dianalisis sesuai masalah yang dikaji. Data terpenting dalam penelitian ini adalah kosakata, frasa, maupun kalimat yang mengandung unsurunsur proklitik pada pronomina persona pertama, kedua, maupun ketiga, baik tunggal maupun jamak.

Untuk memperoleh data yang memadai, digunakan tiga metode pengumpulan data. Pertama, metode simak (pengamatan/observasi) yaitu metode yang digunakan untuk memperoleh data dengan melakukan penyimakan terhadap penggunaan bahasa (Mahsun, 2007: 242). Secara konkret, dalam metode ini, peneliti menyimak, mendengar, dan mencatat data yang didapat dari penutur. Data yang diperoleh dari informan dicatat pada kartu data. Pencatatan tersebut dilakukan untuk mengurangi tingkat kesalahan yang mungkin terjadi dalam penelitian ini, Muhammad (2012: 195). Kedua, metode cakap (wawancara) yaitu melakukan percakapan dengan para informan. Metode cakap ini memiliki teknik dasar berupa teknik pancing yang diikuti dengan teknik lanjutan, yaitu teknik cakap semuka. Pada pelaksanaan teknik cakap semuka ini, peneliti langsung melakukan percakapan dengan informan dengan bersumber pada pancingan yang sudah disiapkan (berupa daftar pertanyaan) atau secara spontanitas atau pancingan dapat muncul di tengah-tengah percakapan Mahsun (2007: 250).

Selain metode simak, peneliti juga menggunakan motode wawancara dengan teknik pengajuan daftar 200 kosakata Swadesh dan 200 kosakata budaya. Kosakata tersebut bertujuan untuk menjaring kosakata pokok BT beserta cara penyebutan/pelafalannya. Kosakata tersebut telah didaftarkan sebelumnya pada beberapa lembar kertas untuk ditanyakan kepada penutur bahasa daerah mengenai penggunaannya pada komunikasi sehari-hari, baik tempat maupun situasi digunakannya kata-kata tersebut. Ketiga, metode introspeksi atau metode penyediaan data merupakan pemanfaatan intuisi kebahasaan peneliti dalam meneliti bahasa yang dikuasai (bahasa ibunya) sehingga penyediaan data sesuai dengan tujuan penelitian (Mahsun, 2008: 102). Metode ini digunakan untuk mengecek validitas dan dapat menghadirkan data informan. Jika terdapat data yang meragukan, lebih cepat dikenali berdasarkan intuisi kebahasaan yang dimiliki peneliti.

\section{Hasil dan Pembahasan}

Berdasarkan hasil analisis data, pronomina dalam BT terdiri atas pronomina persona pertama, kedua, dan ketiga. Setiap pronomina BT bersifat tunggal dan jamak. Dalam BT, ditemukan pronomina persona yak 'saya', persona pertama jamak tit/tat 'kita' dan am 'kami'; persona kedua tunggal meu 'kamu', persona kedua jamak $h$-'kalian', morfem $h$ merupakan morfem terikat pada kata kerja (verba) dan kata depan (partikel preposisi) yang mengikutinya; persona ketiga tunggal pada morfem $i$-'dia'; dan persona ketiga jamak pada morfem $l$ - atau $s i$ - 'mereka'. Morfem $l$ bentuk terikat atau tidak dapat berdiri sendiri tanpa ada kata kerja (verba) yang mengikutinya.

Pada isi tabel, selain dijelaskan bentuk proklitik yang bebas dan bentuk terikat pada kata kerja, kata depan, dan kata benda, dijelaskan pula bentuk abreviasi maupun pergantian pergeseran huruf. Berikut ini, 
dijabarkan beberapa contoh kata dalam kalimat yang mengandung unsur proklitik pronomina persona pertama tunggal dan jamak, pronomina persona kedua tunggal dan jamak, dan pronomina persona ketiga tunggal dan jamak.

Tabel 1

Proklitik Pronomina Persona Pertama Tunggal dan Jamak

\begin{tabular}{|l|l|l|}
\hline Pronomina & $\begin{array}{l}\text { Bentuk } \\
\text { k-, } \text { ta-, } \\
\text { dan } \boldsymbol{a} \text { - }\end{array}$ & Konteks \\
\hline $\begin{array}{l}\text { Persona } \\
\text { pertama }\end{array}$ & -han & saya pergi \\
\hline $\begin{array}{l}\text { Persona } \\
\text { Pertama } \\
\text { Jamak }\end{array}$ & $\begin{array}{l}\text { tat-tiam } \\
\text { a-pe }\end{array}$ & $\begin{array}{l}\text { kita pusing } \\
\text { kami buat }\end{array}$ \\
\hline
\end{tabular}

Berikut ini contoh kalimat pada proklitik pronomina persona tunggal dan jamak pada kata k-han 'saya pergi', ta-ttiam 'saya membawa', dan a-pe.

1. k-han doba li 'saya pergi di kebun' (struktur bebas berdasarkan stuktur BT). Kalimat yang mengikuti struktur BT dan belum terjadi abreviasi seperti: yak han doba li 'saya pergi kebun di' (terjemahan kata per kata berdasarkan deretan kata dalam kalimat). Pada morfem $k$ - dari kata dasar yak, terjadi abreviasi atau pemendekan pada dua huruf di depannya (lesapan), yakni huruf /a/ dan /y/.

2. lailu ndara dadi ta-ttiam 'terlalu berombak jadi kita pusing' (struktur bebas berdasarkan stuktur BT). Kalimat yang mengikuti struktur BT dan belum terjadi abreviasi seperti: lailu ndara dadi tit ttiam 'ombak terlalu jadi kita pusing' (terjemahan kata per kata berdasarkan deretan kata dalam kalimat). Pada morfem ta- dari kata dasar tit, terjadi abreviasi atau pemendekan atau pergeseran huruf. Abreviasi tersebut terjadi karena adanya pelesapan satu huruf /t/ di depannya dan terdapat pula pergantian huruf /i/ menjadi /a/ di tengah.

3. a-pe um!' kami membuat rumah!' (truktur bebas berdasarkan stuktur BT). Kalimat yang mengikuti struktur BT dan belum terjadi abreviasi seperti: am pe um 'kami membuat rumah' (terjemahan kata per kata berdasarkan deretan kata dalam kalimat). Pada morfem $a$ - dari kata dasar am, terjadi abreviasi atau pelesapan pada huruf $/ \mathrm{m} / \mathrm{di}$ depannya.

Tabel 2

Proklitik Pronomina Persona KeduaTunggal dan Jamak

\begin{tabular}{|l|l|l|}
\hline Pronomina & $\begin{array}{l}\text { Bentuk } \boldsymbol{m} \text { - } \\
\text { dan } \boldsymbol{h} \text { - }\end{array}$ & Konteks \\
\hline $\begin{array}{l}\text { Persona } \\
\text { kedua } \\
\text { tunggal }\end{array}$ & m-han & kamu pergi \\
\hline $\begin{array}{l}\text { Persona } \\
\text { kedua } \\
\text { Jamak }\end{array}$ & h-anappo & $\begin{array}{l}\text { kalian ke } \\
\text { bawah }\end{array}$ \\
\hline
\end{tabular}

Berikut ini contoh kalimat pada proklitik pronomina persona kedua dan jamak tunggal pada kata m-han 'kamu pergi' dan h-anappo 'kalian ke bawah'.

4. Sambeang Jumat togu m-han loli? 'setelah selesai salat Jumat kamu pergi ke mana?' (struktur bebas berdasarkan struktur BT). Kalimat yang mengikuti struktur BT dan belum terjadi abreviasi seperti: Sambeang Jumat togu meu han loli? 'salat Jumat selesai kamu pergi mana?' (terjemahan kata per kata berdasarkan deretan kata dalam kalimat). Pada morfem meu, terjadi abreviasi atau pelesapan dua huruf morfem $m$ - di depannya, yaitu huruf /e/ dan /u/.

5. h-anappo am um li 'kalian ke bawah di rumah kami' (truktur bebas berdasarkan stuktur BT). Kalimat yang mengikuti struktur BT sebagai berikut: hanappo am um $l i$ 'kalian ke bawah kami rumah di' (terjemahan kata per kata berdasarkan deretan kata dalam kalimat). Morfem $h$ merupakan morfem terikat. Pada morfem tersebut, tidak terjadi abreviasi.

Tabel 3

Proklitik Pronomina Persona Ketiga Tunggal Jamak

\begin{tabular}{|l|l|l|}
\hline Pronomina & $\begin{array}{l}\text { Bentuk } \boldsymbol{i} \text { - } \\
\text { dan } \boldsymbol{l} \text { - }\end{array}$ & Konteks \\
\hline $\begin{array}{l}\text { Persona } \\
\text { ketiga } \\
\text { tunggal }\end{array}$ & -nini & milik dia \\
\hline $\begin{array}{l}\text { Persona } \\
\text { ketiga jamak }\end{array}$ & l-am & $\begin{array}{l}\text { mereka } \\
\text { melihat } \\
\text { dia (benda) }\end{array}$ \\
\hline
\end{tabular}




\begin{tabular}{|l|l|l|}
\hline n-tattae & $\begin{array}{l}\text { tumbuh } \\
\text { dia (insani) } \\
\text { berbohong }\end{array}$ \\
\hline
\end{tabular}

Berikut ini contoh kalimat pada proklitik pronomina persona ketiga tunggal pada morfem inini 'milik dia', dan ketiga jamak yaitu pada morfem $l$-am

'mereka melihat', ntub 'dia (benda) tumbuh, dan ntattae 'dia (insani) berbohong'.

6. i-nini tas ne 'tas ini milik dia'(truktur bebas berdasarkan stuktur BT). Kalimat yang mengikuti struktur BT seperti ini: inini tas ne 'dia milik tas ini' (terjemahan kata per kata berdasarkan deretan kata dalam kalimat). Morfem $i$ - berposisi sebagai morfem terikat. Pada morfem tersebut, tidak terjadi abreviasi.

7. l-am pesawat nopa 'mereka melihat pesat terbang' (truktur bebas berdasarkan stuktur BT). Terjemahannya berpola seperti terjemahan kata per kata dalam kalimat tersebut. Morfem $i$ - berposisi sebagai morfem terikat. Pada morfem tersebut, tidak terjadi abreviasi.

8. lalho n-tub 'tumbuh gigi (nama benda)' (struktur bebas berdasarkan stuktur BT). Terjemahannya berpola sama dengan terjemahan kata per kata dalam kalimat. Morfem $n$ - berposisi sebagai morfem terikat. Pada morfem tersebut, tidak terjadi abreviasi.

9. wang idia n-tattae hia 'anak itu dia suka berbohong' (truktur bebas [berdasarkan stuktur BT]). Kalimat yang diterjemahkan mengikuti struktur seperti ini: wang idia ntattae hia 'anak itu dia berbohong suka' (terjemahan kata per kata berdasarkan deretan kata dalam kalimat). Morfem $n$ berposisi sebagai morfem terikat. Pada morfem tersebut, tidak terjadi abreviasi.

\section{Simpulan}

Berdasarkan hasil identifikasi, klasifikasi, dan analisis data yang telah dilakukan, ditemukan beberapa simpulan mendasar. Pertama, ditemukan tiga jenis proklitik pronomina persona pertama, kedua, dan ketiga pada bahasa Taba. Pronomina persona pertama terbagi atas pronomina persona pertama tunggal dan pronomina persona jamak. Pada pronomina persona pertama tunggal, ditemukan tiga bentuk proklitik, yaitu morfem $k$ - 'saya', $n$ - 'dia (benda)', dan $n$ - 'dia (insani)'. Pada pronomina pertama jamak ditemukan dua bentuk proklitik yaitu tit/tat'kita' dan $a$ - 'kami'. Untuk pronomina persona kedua tunggal dan jamak, ditemukan satu contoh bentuk pada morfem $m$ - 'kamu' dan persona kedua jamak pada morfem $h$ - 'kami'. Pada persona ketiga tunggal, ditemukan satu contoh, yaitu pada morfem $i$ - 'dia'. Pada persona ketiga jamak, ditemukan satu bentuk proklitik, yaitu morfem $l$ - atau si 'mereka.' Kedua, proklitik bahasa Taba melekat pada kata kerja (verba), kata depan (partikel preposisi), dan kata benda (nomina) yang bersifat singularis posesif. Pada proklitik pronomina persona ketiga jamak bahasa Taba, terdapat salah satu kata (beda tulisan, tetapi sama makna), yaitu kata (si) yang dapat berdiri sendiri.

Penelitian lebih lanjut tentang klitik bahasa Taba yang lebih komprehensif perlu dilakukan. Hal ini dimaksudkan agar struktur bahasa Taba dapat terdokumentasi dengan baik.

\section{Daftar Pustaka}

Alwi. dkk. (1998). Tata Bahasa Baku Bahasa Indonesia. Jakarta: Pusat Bahasa dan Balai Bahasa.

Bowden, Jhon. (2001). Taba: Description of an South Halmahera Language. Disertasi. Australian National University, Australia.

Buha, Aritorang. (2018). Klitik Klausa Pasif Bahasa Manggarai Dialek Barat. Buletin Al-turas, XXIV (1): 51-67. Dalam http:

//journal.uinjkt.ac.id/index.php/alturats/a rticle/download/7191/4586.

Hanafi, Hilaluddin. (2009). Pola Konstruktursi Klitik Bahasa Tolaki. Humaniora, 21 (3): 294-300. Dalam https: //id.123dok.com/document/y4 gjr09ypola-konstruksi-klitik-bahas a-tolakihanafi-humaniora-973-1759-2-pb.html.

Mahsun. (2007). Metode Penelitian Bahasa (Tahapan, Strategi, Metode, dan 
Tekniknya). Jakarta: Raja Grafindo Persada.

Iuhammad. (2012). Metode dan Teknik Analisis Data Linguistik. Yogyakarta: Liebe Book Press.

amarin, William J. (1988). Ilmu Bahasa Lapangan. Yogyakarta: Kanisius.

arage, Japen, (2013). "Beberapa Fakta Klitika dalam Bahasa Inggris, Indonesia, Arab, dan Spanyol: Sebuah Studi Kontrastif". Dalam Prosoding Seminar Internasional, Studi Bahasa dari Berbagai Perspektif (hlm. 812-821). Yogyakarta: Program
Studi S-2 Linguistik, bekerja sama dengan Jurusan Sastra Indonesia, Fakultas Ilmu Budaya, UGM Yogyakarta dan Gress Publishing.

Sudaryanto. (1992). Metode Linguistik. Yogyakarta: Gajamada University Press.

Sultana. (2017), Analisis Bentuk Klitik dalam Bahasa sasak Dialek Meno-Mene. Lingua, 14 (1): 67-78. Dalam http: //lingua.pusatbahasa.or.id/index.php/ling ua/article/view/241. 